\title{
Surprisingly small HONO emissions from snow surfaces at Browning Pass, Antarctica
}

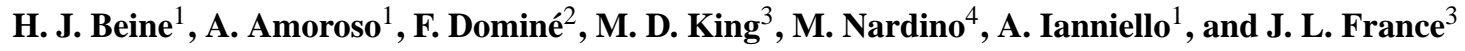 \\ ${ }^{1}$ C.N.R. - IIA, Via Salaria Km 29,3, 00016 Monterotondo Scalo (Roma), Italy \\ ${ }^{2}$ CNRS - LGGE, BP 96, 54 rue Molière, 38402 Saint Martin d'Hères, France \\ ${ }^{3}$ Department of Geology, Royal Holloway University of London, Egham, Surrey, TW20 0EX, UK \\ ${ }^{4}$ C.N.R. - IBIMET, Sezione di Bologna, via Gobetti 101, 40129 Bologna, Italy
}

Received: 26 October 2005 - Published in Atmos. Chem. Phys. Discuss.: 17 January 2006

Revised: 20 April 2006 - Accepted: 23 May 2006 - Published: 3 July 2006

\begin{abstract}
Measured Fluxes of nitrous acid at Browning Pass, Antarctica were very low, despite conditions that are generally understood as favorable for HONO emissions, including: acidic snow surfaces, an abundance of $\mathrm{NO}_{3}^{-}$anions in the snow surface, and abundant UV light for $\mathrm{NO}_{3}^{-}$photolysis. Photochemical modeling suggests noon time $\mathrm{HONO}$ fluxes of $5-10 \mathrm{nmol} \mathrm{m}^{-2} \mathrm{~h}^{-1}$; the measured fluxes, however, were close to zero throughout the campaign. The location and state of $\mathrm{NO}_{3}^{-}$in snow is crucial to its reactivity. The analysis of soluble mineral ions in snow reveals that the $\mathrm{NO}_{3}^{-}$ion is probably present in aged snows as $\mathrm{NaNO}_{3}$. This is peculiar to our study site, and we suggest that this may affect the photochemical reactivity of $\mathrm{NO}_{3}^{-}$, by preventing the release of products, or providing a reactive medium for newly formed HONO. In fresh snow, the $\mathrm{NO}_{3}^{-}$ion is probably present as dissolved or adsorbed $\mathrm{HNO}_{3}$ and yet, no HONO emissions were observed. We speculate that $\mathrm{HONO}$ formation from $\mathrm{NO}_{3}^{-}$photolysis may involve electron transfer reactions of $\mathrm{NO}_{2}$ from photosensitized organics and that fresh snows at our site had insufficient concentrations of adequate organic compounds to favor this reaction.
\end{abstract}

\section{Introduction}

The production of gas phase HONO from snow surfaces is generally understood to proceed through a mechanism similar to that of $\mathrm{NO}_{x}$ starting by the photolysis of $\mathrm{NO}_{3}^{-}$in the snow surface (Honrath et al., 2000), analogous to reactions in liquid phase (Mack and Bolton, 1999). Fluxes were quantified above snow surfaces at Alert, Nunavut as ca. $40 \mathrm{nmol} \mathrm{m}^{-2} \mathrm{~h}^{-1}$ (Zhou et al., 2001), and $5-10 \mathrm{nmol} \mathrm{m}^{-2} \mathrm{~h}^{-1}$ at Summit Greenland (Honrath et al., 2002) (both noon-time maximum values). The absence

Correspondence to: H. J. Beine

(harry@iia.cnr.it) of measurable HONO fluxes in the marine Arctic at NyÅlesund, Svalbard was assigned to an alkaline snow surface, which prevented the emission of HONO (Beine et al., 2003). However, in fresh, acidic snow in ozone depleted airmasses, HONO emissions of up to $60 \mathrm{nmol} \mathrm{m}^{-2} \mathrm{~h}^{-1}$ were found at Ny-Ålesund (Amoroso et al., 2005). The importance of the surface snow $\mathrm{pH}$ was shown again in the Italian Apennines, where up to $120 \mathrm{nmol} \mathrm{m}^{-2} \mathrm{~h}^{-1} \mathrm{HONO}$ were deposited on to snow surfaces that were rendered alkaline by Saharan dust deposition (Beine et al., 2005).

We measured HONO fluxes, snow chemical composition and snow optical properties at Browning Pass, Antarctica; a site close to the Ross Sea. All observed conditions were generally favorable for HONO emissions, yet we observed fluxes larger than $5 \mathrm{nmol} \mathrm{m}^{-2} \mathrm{~h}^{-1}$ only on two short occasions under very specific local air flow conditions. This paper discusses the surprisingly low HONO emissions.

\section{Experimental}

Measurements were carried out at Browning Pass $\left(74^{\circ} 36.915^{\prime} \mathrm{S}, 163^{\circ} 56.487^{\prime} \mathrm{E}\right.$ ) (Fig. 1), which is located $10.1 \mathrm{~km}$ from the Italian coastal Antarctic station "Mario Zucchelli" (formerly Terra Nova Bay). The site does not receive direct sea spray, and is, during the rare katabatic flow from the Boomerang and Campbell glaciers somewhat removed meteorologically from marine influences by the Northern Foothills (up to $1000 \mathrm{~m}$ altitude); however, the marine influence is prevailing. At this field site, which was accessed by helicopter daily, we measured HONO fluxes, chemical and optical snow properties between 9 November (doy 314) and 28 (doy 333), 2004.

\subsection{HONO fluxes}

Fluxes of HONO were derived from independent chemical measurements of $\mathrm{HONO}$ at two sampling heights above the

Published by Copernicus GmbH on behalf of the European Geosciences Union. 


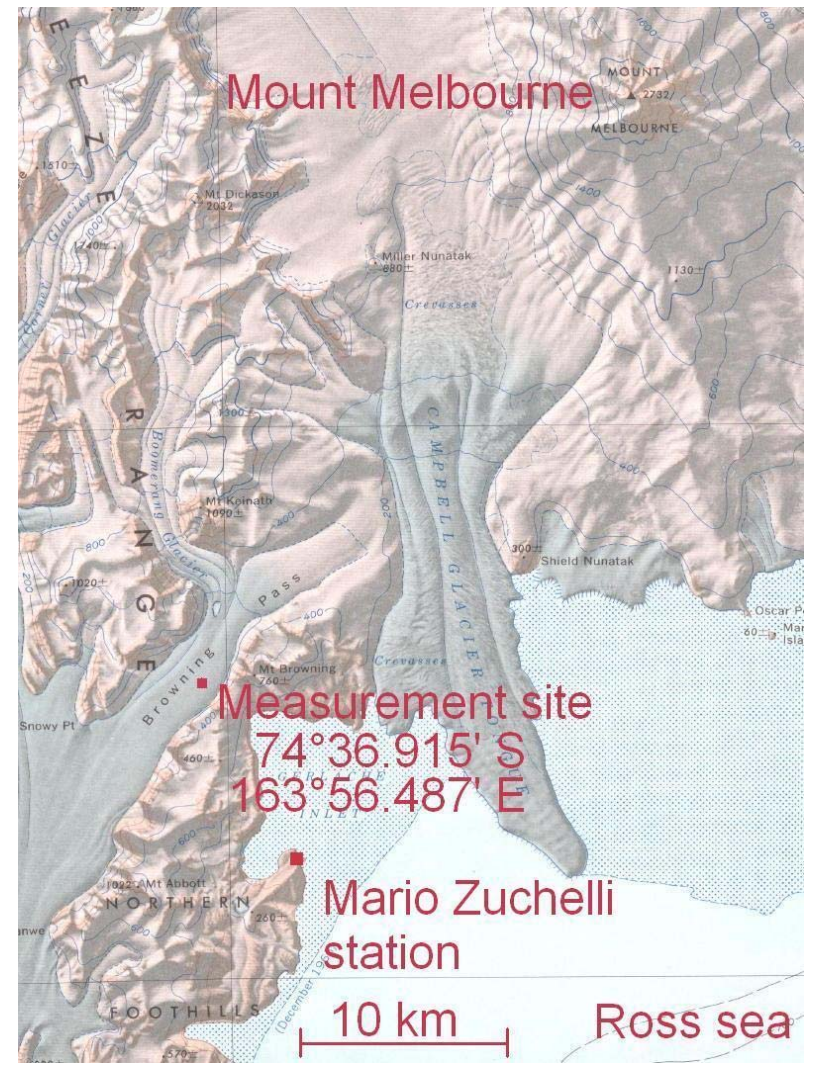

Fig. 1. Map of the area surrounding our measurement site at Browning Pass, near the Italian Mario Zucchelli (formerly Terra Nova Bay) station.

snow surface (25 and $150 \mathrm{~cm}$ ) and simultaneous temperature and wind speed measurements at the same heights. The glacier was reasonably flat for a radius of hundreds of meters in all directions. The snow surface showed alternating outcropping hard windpacks and softer layers, and steps between these two types of snow could reach $30 \mathrm{~cm}$. The large snowfall of 17-18 November temporarily smoothed the snow surface. The only obstruction to the local windfield were our instrument containers, which were located ca. $20 \mathrm{~m}$ from the sampling site, perpendicular to the prevailing wind directions, which were SSW and NE, roughly parallel to the glacier.

We sampled HONO at 25 and $150 \mathrm{~cm}$ above the snow surface, using two independent $2.5 \mathrm{~cm}$ (I.D.) light-shielded inlet lines of $20 \mathrm{~m}$ length at flow rates of $38 \mathrm{~L} \mathrm{~min}^{-1}$ to feed the sample into the container where the instrument was placed. The samples were taken from this flow through ca. $50 \mathrm{~cm}$ of $1.58 \mathrm{~mm}$ (I.D.) tubing at $3 \mathrm{~L} \mathrm{~min}^{-1}$. The total residence time in the inlet lines was ca. $17 \mathrm{~s}$. Both inlet lines were identical, and no null-gradients between the two inlets were detected.

The details of our measurement technique, including possible interferences, are discussed in Beine et al. (2005) and Amoroso et al. (2005); briefly; gaseous HONO was trapped quantitatively in a 10-turn glass coil sampler using 1-mM phosphate buffer ( $\mathrm{pH}$ 7). The scrubbing solution was then derivatized with sulfanilamine (SA)/ N-(1-naphtyl)ethylendiamine (NED), subsequently analyzed using highperformance liquid chromatography (HPLC), and detected by vis absorption. Typical operation conditions were: sample flow: $3 \mathrm{~L} \mathrm{~min}^{-1}$, solution flow: $0.2 \mathrm{~mL} \mathrm{~min}^{-1}$, derivatization conditions: $5 \mathrm{~min}$ at $45^{\circ} \mathrm{C}$; HPLC: loop: $300 \mathrm{~mL} \mathrm{C18}$ reverse phase column (Varian), eluent: $20 \%$ acetonitrile in $15 \mathrm{mM} \mathrm{HCl}$.

To characterize the surface-atmosphere interaction and to determine the turbulent fluxes we used a UVW tri-propeller anemometer (Gill, model 200-27005), which measured the three orthogonal wind vectors at $1 \mathrm{~Hz}$ sampling frequency. Fluxes were computed using the eddy covariance technique in the post processing. Additionally, profile measurements of air temperatures and wind speeds were performed to be able to compute fluxes of chemical species. The instrument was set up ca. $10 \mathrm{~m}$ from the chemical measurements. The derivation of HONO fluxes from this mixed eddy covariance and gradient technique is fully described in Beine et al. (2003, 2005).

The mechanical tri-propeller was calibrated against 3-D sonic anemometers under various field conditions; offsets are taken into account in the computational procedures. The use of a mechanical device introduces a threshold wind speed $\left(0.25 \mathrm{~m} \mathrm{~s}^{-1}\right)$. Consequently a detection limit for the observed HONO flux does not depend on the detection limit of the chemical HONO measurements alone. The $3 \sigma$ detection limit for the individual HONO measurement was $<0.5 \mathrm{pmol} \mathrm{mol}^{-1}$. In the simplest approach we use this value also for the minimum detectable $\Delta_{\mathrm{HONO}}\left(=\left[\mathrm{HONO}_{\text {down }}\right]-\right.$ $\left.\left[\mathrm{HONO}_{\text {up }}\right]\right)$. Two chemical samples were taken at the same time, and analyzed over a 10 min period; the fluxes were calculated for $10 \mathrm{~min}$ envelopes around this time of sampling. At the threshold wind speed the minimum $\Delta_{\text {HONO }}$ translates into a minimum observable flux of ca. $0.3 \mathrm{nmol} \mathrm{m}^{-2}$ $\mathrm{h}^{-1}\left(0.33 \mathrm{nmol} \mathrm{m}^{-2} \mathrm{~h}^{-1}\right.$ to $0.28 \mathrm{nmol} \mathrm{m} \mathrm{m}^{-2} \mathrm{~h}^{-1}$ under neutral conditions between $-40^{\circ} \mathrm{C}$ and $0^{\circ} \mathrm{C}$ ).

At mixing ratios above the $10 \sigma$ quantification level $\left(1.6 \mathrm{pmol} \mathrm{mol}^{-1}\right)$ the error is ca. $30 \%$. The error attached to the flux gradient method was estimated through a comparison of sensible heat fluxes measured by the tri-propeller and a fast temperature sensor and analysis by eddy covariance and gradient flux calculations. The mean relative error between these two techniques was around $15 \%$. Because both air temperatures and HONO mixing ratios are scalars, we can assume that the flux of a generic scalar variable in similar atmospheric conditions shows similar errors. Using the HONO data as if they were available at $1 \mathrm{~Hz}$, we can calculate an error using eddy covariance theory; such a (hypothetical) error would come to $35 \%$. Taking into account the difference between the eddy covariance and gradient flux techniques, our HONO fluxes generated by the gradient flux theory have a (mean) total error on the order of $50 \%$. 


\subsection{Snow optical properties}

The optical properties (scattering and absorption cross sections) of the Antarctica snowpacks found at Browning Pass were determined by an experimental and modeling method we have used previously in mid-latitude snowpacks (Fisher et al., 2005), and sea ice (King et al., 2005), where details can be found. The modeling was originally described in LeeTaylor and Madronich (2002). Briefly, the optical properties of a snowpack can be defined and constrained by measuring the wavelength-resolved albedo and the wavelengthresolved transmission of light through snowpack. The transmission measurements are made at a series of depths below a starting depth a few centimeters below the surface of the snowpack where the optical e-folding depth, $\varepsilon$, is constant and only very weakly dependent on the solar zenith angle. (The optical properties of snowpacks are described well by Lee-Taylor and Madronich (2002), Warren (1982), King and Simpson (2001), and Simpson et al. (2002). The albedos of the snowpack were measured using a GER 1500 spectrometer $(\lambda=300-1000 \mathrm{~nm})$ and measured relative to a reflectance standard under identical light conditions. The e-folding depth of the snowpack (the depth of snowpack to reduce the light intensity by $1 / \mathrm{e}$ of its initial value) was measured by probing the snow with a flat plate irradiance probe connected to a spectrometer $(\lambda=280-449 \mathrm{~nm})$ at different depths within the snowpack. During the transmission measurement any changes in the downwelling irradiance were measured by the GER 1500 fitted with a cosine collector. The downwelling atmospheric flat-plate irradiance was measured throughout the campaign by the GER1500 fitted with a cosine corrector every $1-5 \mathrm{~min}$ (more technical information on the GER1500 and the spectrometer used to sample irradiance in the snow can be found in Fisher et al., (2005)).

\subsection{Snow sampling and analysis}

Snow was sampled and analyzed in a manner essentially similar to that described by Dominé et al. $(2002 ; 2004)$ for physical measurements. Polyethylene gloves were used to avoid contamination, and snow was sampled into polyethylene sampling vials. For each snow layer, two sets of triplicate samples were taken for anions and cations, respectively. Samples were usually melted and analyzed on site by ion chromatography within $12 \mathrm{~h}$ of sampling, and in a few cases were stored frozen for up to $48 \mathrm{~h}$ before analysis.

Melted snow was analyzed by ion chromatography (Dionex IC mod. DX120 and DX100) using Dionex AS12 and CS12 columns for anions and cations, respectively, as detailed in Allegrini et al. (1999) and Domine et al. (2004). The $3 \sigma$ limit of detection was between $0.01 \mu \mathrm{eq}$ (for $\mathrm{NO}_{3}^{-}$) and $0.50 \mu$ eq (for $\mathrm{Ca}^{2+}$ ). It was $0.04 \mu$ eq for $\mathrm{Na}^{+}$.

\section{Photochemistry and Photochemical Model}

\subsection{Photochemistry of the Nitrate Ion in the Snowpack}

The aim of the optical measurements of the snowpack was to calculate the photolysis rate, $\mathrm{J}(\mathrm{NO})_{3}^{-}$of nitrate in the snowpack and to estimate the expected molecular fluxes of gasphase $\mathrm{NO}_{2}$ and $\mathrm{HONO}$ from the snowpack. The photolysis of nitrate in the snowpack can lead to gas phase nitrogen dioxide production or formation of nitrite, $\mathrm{NO}_{2}^{-}$, (Chu and Anastasio, 2003; Cotter et al., 2003; Domine and Shepson, 2002; Dubowski et al., 2001; 2002; Couch et al., 2000; Dubowski and Hoffmann, 2000; Honrath et al., 2000):

$\mathrm{NO}_{3}{ }^{-}+h v \rightarrow \mathrm{NO}_{2}+\mathrm{O}^{-}$
$\mathrm{NO}_{3}{ }^{-}+h v \rightarrow \mathrm{NO}_{2}{ }^{-}+\mathrm{O}$

The resulting radical oxygen anion will form the hydroxyl radical,

$\mathrm{O}^{-}+\mathrm{H}_{3} \mathrm{O}^{+} \rightarrow \mathrm{OH}+\mathrm{H}_{2} \mathrm{O}$

The source of HONO in the snowpack is probably from one or more of the following three sources:

1) Photo production of nitrite, $\mathrm{NO}_{2}^{-}$, from nitrate photolysis in snowpack. The nitrite is protonated and desorbs from the snow grains as HONO.

$\mathrm{NO}_{2}{ }^{-}+\mathrm{H}_{3} \mathrm{O}^{+} \rightarrow \mathrm{HONO}+\mathrm{H}_{2} \mathrm{O}$

2) Recombination of $\mathrm{OH}$ and $\mathrm{NO}$ radical within the snowpack, (Mack and Bolton, 1999).

$\mathrm{NO}+\mathrm{OH} \rightarrow \mathrm{HONO}$

The sources of NO may be the photolysis of nitrite that is more photolabile than nitrate under natural sunlight. The source of $\mathrm{OH}$ radicals can be the photolysis of nitrate and hydrogen peroxide. The photolysis of $\mathrm{H}_{2} \mathrm{O}_{2}$ may be a more efficient production route to produce $\mathrm{OH}$ radicals than nitrate depending on the concentrations of $\mathrm{H}_{2} \mathrm{O}_{2}$ and nitrate within the snowpack, (Chu and Anastasio, 2005).

$\mathrm{NO}_{2}^{-}+h v \rightarrow \mathrm{NO}+\mathrm{O}^{-}$

3) Electron transfer reactions from photosensitized phenoxy groups in organic matter to $\mathrm{NO}_{2}$. This mechanism has been demonstrated by George et al., (2005) on the surface of organic bulk substrates during laboratory experiments, but not on ice surfaces. A recent study (Stemmler et al., 2006) shows that HONO is produced in photo-induced reactions on natural humic acids from $\mathrm{NO}_{2}$ under the influence of visible light (400-700 nm). In Antarctic snow, the importance of this pathway remains speculative, but it could possibly take place on organic aerosols that are known to exist in Antarctic snow (e.g. Cincinelli et al., (2001)), or possibly on sea salt or ice surfaces with adsorbed organic photosensitizers. 
Table 1. Observed HONO fluxes [nmol m${ }^{-2} \mathrm{~h}^{-1}$ ].

\begin{tabular}{|c|c|c|c|c|}
\hline & All data & Detected $>0.3$ & Detected $<-0.3$ & $\begin{array}{l}\text { Below method } \\
\text { detection limits }\end{array}$ \\
\hline $\mathrm{N}$ & 1440 & 675 & 413 & 352 \\
\hline Minimum & -26.111 & 0.300 & -26.111 & -0.300 \\
\hline Maximum & 29.566 & 29.566 & -0.303 & 0.298 \\
\hline Mean & 0.229 & 1.750 & -1.831 & 0.022 \\
\hline Median & 0.579 & 3.140 & -3.131 & 0.023 \\
\hline Upper $95 \% \mathrm{CI}^{\text {(a) }}$ & 0.801 & 3.439 & -2.776 & 0.039 \\
\hline Lower $95 \% \mathrm{CI}^{(\mathrm{a})}$ & 0.358 & 2.841 & -3.487 & 0.007 \\
\hline Std. Dev. & 4.280 & 3.961 & 3.674 & 0.154 \\
\hline
\end{tabular}

(a) $\mathrm{CI}=$ Confidence Interval.

If mechanism 3 is significant a fraction of $\mathrm{NO}_{2}$ formed in Reaction (1) might be converted to HONO. A flux for that case, however, cannot presently be estimated because of the lack of photo-physical and choromophore abundance data.

These mechanisms (1-3) all require nitrogen oxides and the sources of these nitrogen oxides is thought to be the photolysis of nitrate. Thus, we consider the photolysis of nitrate to produce nitrogen dioxide as a measure of snowpack photochemistry, and photolysis of nitrate to produce nitrite as an estimation of the upper limit of HONO production. The estimate of the flux of HONO from the snowpack is an upper limit because the conversion of nitrite on the snowpack to gaseous HONO is probably not $100 \%$ efficient and because HONO may undergo reactions in the snowpack before being emitted to the atmosphere.

\subsection{Calculating photolysis rates}

The photolysis frequency for Reaction (1) is estimated from a coupled atmosphere-snow radiative-transfer model, TUVsnow, (Lee-Taylor and Madronich, 2002). The model requires knowledge of the optical properties of the snowpack (the scattering and absorption cross-sections), the concentration of nitrate in the snowpack and downwelling irradiance on the snowpack. The cross sections for scattering and absorption are derived from the measured light transmission (efolding depth, $\varepsilon$ ) and albedo of the snowpack measured at Browning pass. The model is described fully in Lee-Taylor and Madronich (2002) and will only be described very briefly here. The model treats the optical properties of the snowpack empirically with two constants $\sigma_{\text {scatt }}$ and $\sigma_{\text {abs }}^{+}$which describe the scattering and absorption properties of the snowpack. With these data the wavelength-resolved actinic flux, $F(\lambda)$, at each point in a $1 \mathrm{~m}$ thick snowbank can be calculated using the DISORT code in the TUV-snow model. The absorption spectrum of nitrate in a thin film of ice, $\sigma(\lambda)$, of Burley and Johnson (1992) was used. For Reaction (1) to produce $\mathrm{NO}_{2}$ the temperature dependent quantum yield, $\Phi(\mathrm{T})$, measured in ice by Chu and Anastastio (2003) was used. For Reaction (2) to produce $\mathrm{NO}_{2}^{-}$(and thus $\mathrm{HONO}$ ), the quantum yield data for ice of Dubowski et al. (2002) was used. A temperatureindependent value of $1.5 \times 10^{-3}$ was taken from Dubowski et al. (2002) and assumed to supersede the older value of 4.5 $\times 10^{-3}$, (Dubowski et al., 2001). With these quantities one can calculate the photolysis frequency, $J$, according to Eq. ():

$J=\int \sigma(\lambda) \Phi(T) F(\lambda) d \lambda$

The photochemical predictions of the model have been shown to be consistent with laboratory measurement of nitrate photochemistry, (Phillips and Simpson, 2005).

\section{Results}

\subsection{HONO Measurements}

Table 1 lists the statistics of the observed HONO fluxes during our campaign split for data below and above the method detection limit. To identify periods during which HONO fluxes were actually significantly different from 0 , we performed statistical analysis and t-tests for data above the detection limits in bins of varying length in time. Consecutive data above (or below) the detection limits of $\pm 0.3 \mathrm{nmol} \mathrm{m}^{-2}$ $\mathrm{h}^{-1}$ fall into an individual bin. The length in time of these bins is shown in Fig. 2c by the size of the symbols, with the smallest size representing a single $10 \mathrm{~min}$ measurement, and the largest symbol representing a $200 \mathrm{~min}$ (20 measurements) period. Figure 2 shows the averages of the detected data in these bins. The median positive flux was $1.66 \mathrm{nmol} \mathrm{m}^{-2} \mathrm{~h}^{-1}$ (mean $2.86 ; 340$ bins); the median negative flux was -1.74 (mean $-2.91,237$ bins). Compared to typical Arctic values of HONO and NOx emissions of around $40 \mathrm{nmol} \mathrm{m}^{-2} \mathrm{~h}^{-1}$ (Beine et al., 2002, Honrath et al., 2002) these values are very small.

Figure 3 shows a detailed view of our measured mixing ratios for DOY 325-330. A diurnal noon time maximum, correlated with the insolation can be discerned in the HONO 
mixing ratios at the two heights with some goodwill. The maximum diurnal variation observed here is $1 \mathrm{pmol} / \mathrm{mol}$.

Dibb et al. (2004) measured HONO mixing rations in the atmosphere (of up to $70 \mathrm{pmol} \mathrm{mol}^{-1}$ ) and in snowpack interstitial air at South Pole. Since values were 5 times higher in snowpack air than in the atmosphere, they concluded that the snowpack must be a strong source of HONO but they did not actually quantify fluxes. Our mixing ratios were mostly below $5 \mathrm{pmol} \mathrm{mol}^{-1}$; the difference in mixing ratios is expected comparing the stable and stratified atmosphere at South Pole (Davis et al., 2001) with a windy site near the coast. Still, Oncley et al. (2004) measured average NOx fluxes at South Pole of ca. $23 \mathrm{nmol} \mathrm{m}^{-2} \mathrm{~h}^{-1}$ (NO $\sim 15 \mathrm{nmol} \mathrm{m}^{-2} \mathrm{~h}^{-1}$ ). If the chemistry is comparable to what was observed at Alert (Beine et al., 2002), NOx and HONO fluxes should be of similar magnitude.

\subsection{Snow structure}

The snow surface at Browning pass is shaped by wind. In late October, it consisted of hard windpacks with a positive relief and of softer layers in hollows, each type covering roughly half of the surface. As observed during our stay, snow layers are formed by wind events that remobilize recent precipitation and exposed layers, and are always discontinuous. As a result, the apparently similar-looking windpacks that outcropped were in fact outcrops of different layers (perhaps 2 to 5) formed at different times, so that spatially variable snow chemistry and physics can be expected. During our stay, snowfalls took place on DOY 311/312 (6-7 November) ( $<1 \mathrm{~mm}$ water equivalent), DOY 322/323 (17-18 November) $(12 \mathrm{~mm})$ and 25 November (DOY 330) $(2.5 \mathrm{~mm})$. The last 2 snowfalls took place under low winds and formed continuous layers that were eventually windblown to form discontinuous layers. Other thin layers with a very small spatial coverage were formed in hollows by wind in the absence of precipitation. Often, these layers were dark, presumably because they had incorporated terrigeneous material. The main four surface layers observed were thus (a) hard windpack, (b) soft windpack, (c) recent windblown snow that has been advected in and that had not yet sintered, (d) fresh precipitation, i.e. recent snowfall before it was windblown. The variations of the surface coverage of these 4 snow types are shown in Fig. 4. The snow stratigraphy is composed of alternating hard windpacks formed of small rounded grains, including an incredibly hard layer of density 0.61 (no melting visible) $40 \mathrm{~cm}$ down in the deep pit we dug, and softer layers composed of larger crystals showing some variable degrees of faceting, of density as low as 0.3 . Numerous ice layers, ice lenses, meltfreeze crusts and layers where some frozen percolating water was present were seen throughout the snowpack, suggesting frequent melting events, and not just in summer. Signs of frozen water were more frequent in softer layers. $120 \mathrm{~cm}$ down, and for a depth of at least $70 \mathrm{~cm}$, all the snow layers showed signs of frozen water, and their density was as high

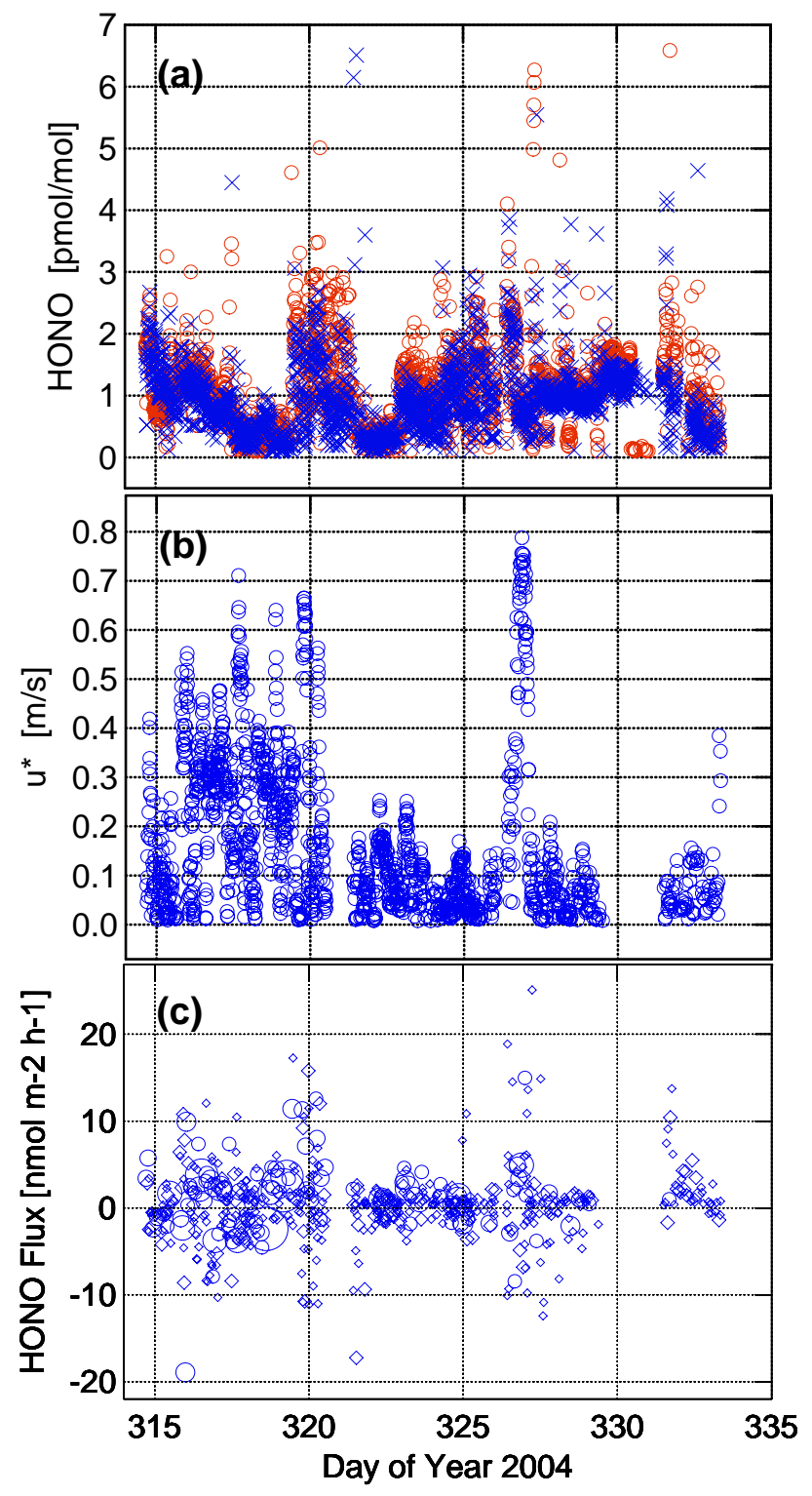

Fig. 2. (a) Timeseries of HONO mixing ratio measured at the lower inlet (red symbols) and the upper inlet (blue symbols). (b) Timeseries of the friction velocity $\mathrm{u}_{*}\left[\mathrm{~m} \mathrm{~s}^{-1}\right]$. (c) Timeseries of averaged HONO fluxes above the detection limits of $\pm 0.3 \mathrm{nmol} \mathrm{m}^{-2}$ $\mathrm{h}^{-1}$. The data are averaged in bins of variable length; the length in time of these bins is shown by the size of the symbols. The smallest size representing a single $10 \mathrm{~min}$ measurement, and the largest symbol representing a $200 \mathrm{~min}$ (20 measurements) period.

as 0.7 . This was certainly the summer melt layer. A $3 \mathrm{~m}$ probe from the bottom of our $1.9 \mathrm{~m}$ pit could not reach solid ice, indicating that our location was in the lower part of the accumulation zone of the glacier. 

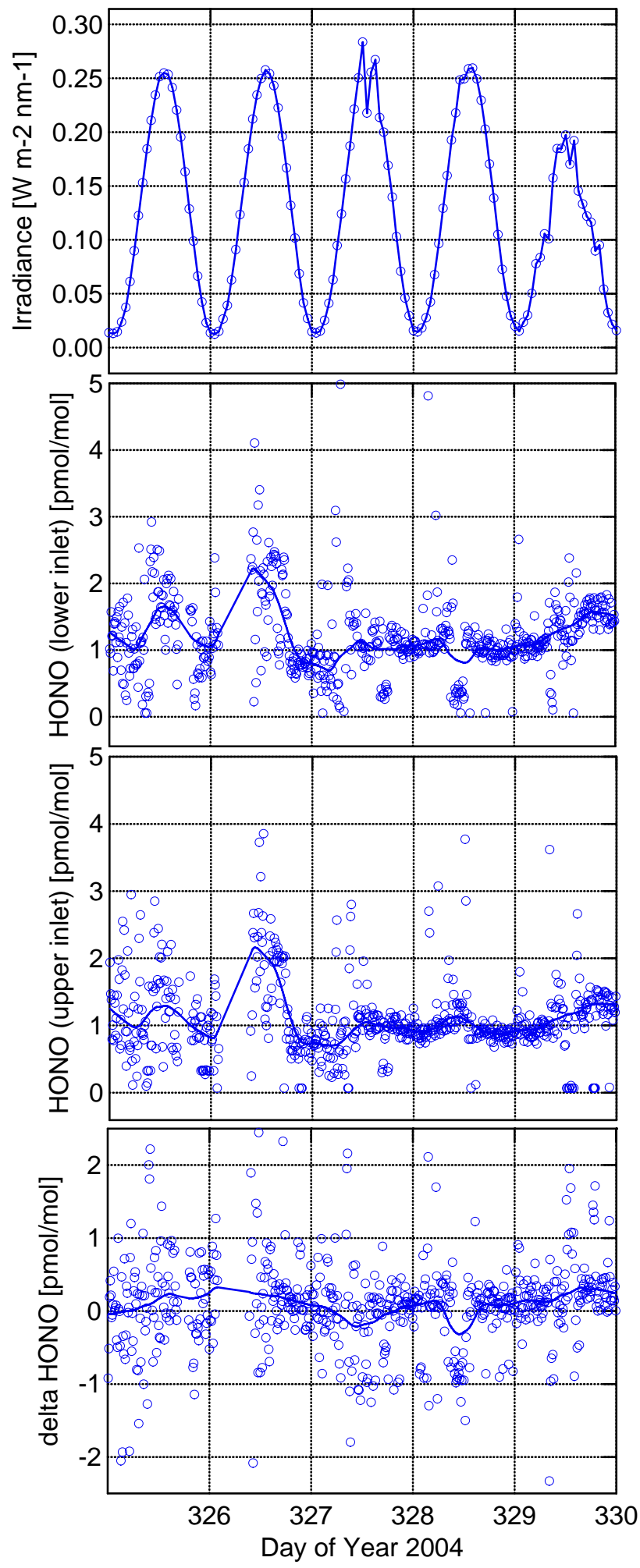

Fig. 3. Detail; (a) Timeseries of irradiance, HONO mixing ratios ((b) down, (c) up), and (d) $\Delta_{\mathrm{HONO}}$ for DOY 325-330.

\subsection{General trends in snow chemistry}

We analyzed 148 triplicate snow samples from Browning Pass, almost all taken within $2 \mathrm{~km}$ from our air sampling site, and $>70 \%$ taken within $100 \mathrm{~m}$. Table 2 sums up correlations and ratios between major soluble mineral ions. It is clear that sea salt has a major influence on snow composition, as most major ions are correlated to $\left[\mathrm{Na}^{+}\right] . \mathrm{Cl}^{-}$and $\mathrm{Mg}^{2+}$ show ion $/ \mathrm{Na}^{+}$ratios very close to those of sea water. $\left[\mathrm{K}^{+}\right]$shows the best correlation with $\left[\mathrm{Na}^{+}\right]$, but surprisingly the ratio, $\left[\mathrm{K}^{+}\right] /\left[\mathrm{Na}^{+}\right]$is $50 \%$ greater than that of sea water. Furthermore, $\mathrm{Cl}^{-}$and $\mathrm{Na}^{+}$were usually the most abundant ions on a molar basis, sometimes exceeding $1000 \mu \mathrm{eq}$, while $\mathrm{Ca}^{2+}, \mathrm{SO}_{4}^{2-}$ and $\mathrm{Mg}^{2+}$ were also abundant, reaching 200 $\mu$ eq. Concentrations of $\mathrm{NO}_{3}^{-}$and $\mathrm{K}^{+}$reached 50 and 40 $\mu \mathrm{eq}$, respectively. The sea is just a few $\mathrm{km}$ from our site, so the trends of Table 2, and the predominance of $\mathrm{Na}^{+}$and $\mathrm{Cl}^{-}$were expected. Table 2 shows that $\mathrm{SO}_{4}^{2-}$ has a source other than sea salt, and this is presumably the oxidation of dimethyl sulfide, with a possible volcanic contribution from Mount Melbourne, some $40 \mathrm{~km}$ away. The influence of marine biogenic products is expected, as marine organic compounds have been identified in snow in this area (Cincinelli et al., 2001). $\mathrm{Ca}^{2+}$ also has an extra source, most likely terrigeneous particles, as a lot of rock outcrops are present nearby. These are mostly granite, but also micashists, and volcanic rocks are present near Mt. Melbourne. Some snow that was windblown during our campaign had a yellow to brownish color, indicating episodes of fairly high concentrations of mineral aerosols. All the snow samples with a high concentration of ions were from the snow that was remobilized during our presence. From their ion balance, most of the snows were acidic. A few samples (20\%) were alkaline. All samples from the hard windpacks and from the 25 November (DOY 330) fall were acidic (pH 5.0 to 5.5). $30 \%$ of recently windblown samples were alkaline. There was no clear correlation between acidity and total ion concentrations, although alkaline samples showed a slight tendency to be more concentrated that acidic ones. The range of concentrations was large; however, that just one highly concentrated sample could change the trend. Regarding $\mathrm{NO}_{3}^{-}$in snow, it is necessary to discuss separately aged and freshly precipitated snows.

\subsection{Origins of nitrate in snow}

Figure 5a shows the excellent correlation between the concentrations of $\mathrm{NO}_{3}^{-}$and $\mathrm{Na}^{+}$in aged snows. The most likely explanation is that gas phase nitric acid reacted with sea salt to release $\mathrm{HCl}$ and form $\mathrm{NaNO}_{3}$ (Fenter et al., 1994). $\mathrm{Na}^{+}$ concentrations are a function of sea salt mass, while the rate of sea salt reaction depends on aerosol surface area. The existence of this excellent correlation suggests that the size distribution of sea salt aerosol varies little at Browning pass. This seems reasonable, given the existence of the Ross sea 
Table 2. Correlations between the concentrations of ions and those of $\mathrm{Na}^{+}$, and comparison of the ion/ $\mathrm{Na}^{+}$ratio to that of sea salt.

\begin{tabular}{|c|c|c|c|c|c|c|}
\hline Ion & $\mathrm{Cl}^{-}$ & $\mathrm{SO}_{4}^{2-}$ & $\mathrm{NO}_{3}^{-}$ & $\mathrm{Ca}^{2+}$ & $\mathrm{Mg}^{2+}$ & $\mathrm{K}^{+}$ \\
\hline Correlation with $\mathrm{Na}^{+(\mathrm{a})}$ & $0.88(0.95)^{(b)}$ & 0.915 & 0.972 & 0.889 & 0.992 & 0.996 \\
\hline Molar ratio $[\mathrm{ion}] /\left[\mathrm{Na}^{+}\right]$ & $0.951(1.22)^{(\mathrm{b})}$ & 0.108 & $0.052^{(\mathrm{c})}$ & 0.090 & 0.110 & 0.033 \\
\hline Sea salt ratio $[$ ion $] /\left[\mathrm{Na}^{+}\right]$ & 1.165 & 0.060 & 0.00003 & 0.022 & 0.113 & 0.022 \\
\hline
\end{tabular}

(a)=Linear correlation coefficient for least square fit.

(b)=Value if four outliers, presumably caused by highly fractionated sea salt, are removed.

(c)=aged snows only.

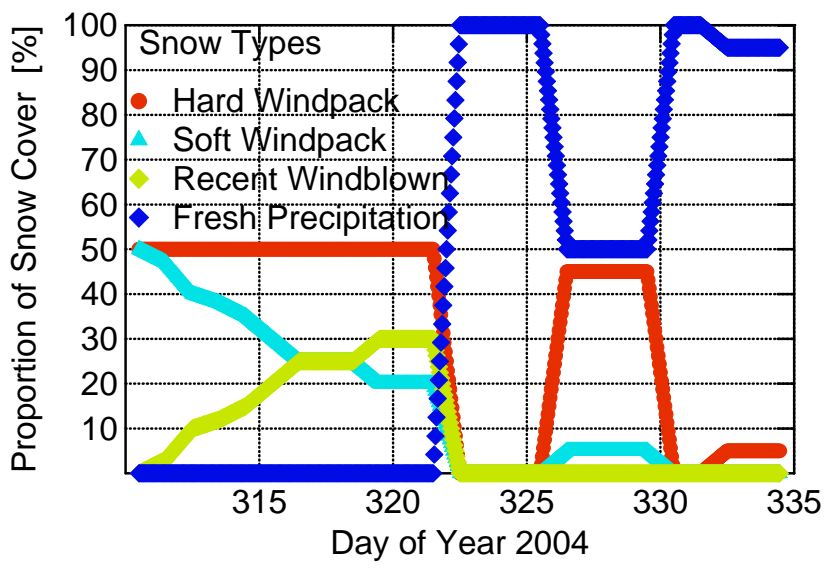

Fig. 4. Relative proportions of the four different surface snows at Browning Pass during the campaign.

polynya, and among the possible sources (Domine et al., 2004) sea salt aerosol probably comes mostly from nearby sea spray. There is also a good correlation between $\left[\mathrm{NO}_{3}^{-}\right]$ and $\left[\mathrm{Ca}^{2+}\right]\left(\mathrm{R}^{2}=0.918\right)$, and it could be argued that $\mathrm{NO}_{3}^{-}$in aged snow comes from the reaction of mineral aerosol with gas phase $\mathrm{HNO}_{3}$. This reaction is fast, with a reaction probability $\gamma>0.01$ on many minerals (Hanisch and Crowley, 2001). However, since $\left[\mathrm{Ca}^{2+}\right]$ and $\left[\mathrm{Na}^{+}\right]$are well correlated, a $\left[\mathrm{NO}_{3}^{-}\right]-\left[\mathrm{Na}^{+}\right]$correlation results also in a $\left[\mathrm{Ca}^{2+}\right]-\left[\mathrm{NO}_{3}^{-}\right]$ correlation, without necessarily a chemical reason. Furthermore, since the correlation with $\mathrm{Ca}^{2+}$ is not as good, our preferred interpretation is that $\mathrm{NO}_{3}^{-}$in aged snows is present as $\mathrm{NaNO}_{3}$, after acid attack of sea salt by $\mathrm{HNO}_{3}$.

Figure $5 \mathrm{~b}$ shows that there is little correlation between $\left[\mathrm{NO}_{3}^{-}\right]$and $\left[\mathrm{Na}^{+}\right]$for fresh snow samples, i.e. in precipitated snows before they were remobilized by wind. The ion balance of almost all fresh samples is acidic, with corresponding $\mathrm{pH}$ values in the range 5-6. The ionic concentrations are also much lower than for many aged snows in the preceding figure. Our interpretation is that the source of $\mathrm{NO}_{3}^{-}$in these snows is gas phase $\mathrm{HNO}_{3}$ that dissolved in the ice to form a solid solution (Thibert and Domine, 1998). Adsorbed $\mathrm{HNO}_{3}$ may also contribute to the $\mathrm{NO}_{3}^{-}$signal (Sokolov and Abbatt,
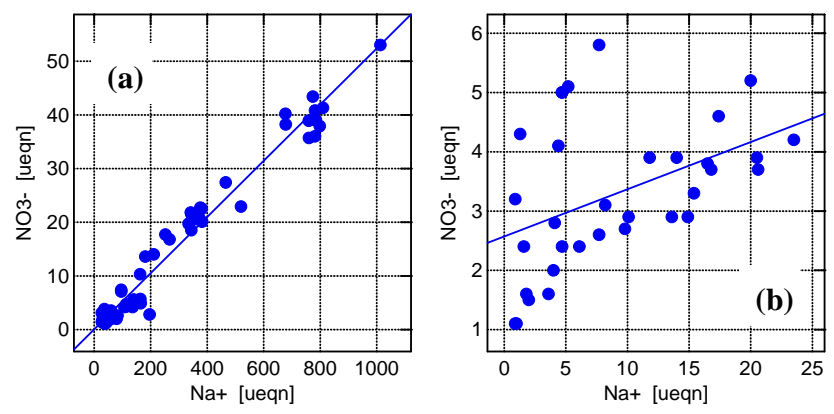

Fig. 5. Correlation between $\mathrm{NO}_{3}^{-}$and $\mathrm{Na}^{+}$for (a) aged snows $\left(\mathrm{NO}_{3}^{-}=0.037+0.052 \mathrm{Na}^{+} ; \mathrm{p}=0.000 ; \mathrm{R}^{2}=0.973\right)$; (b) fresh snows $\left(\mathrm{NO}_{3}^{-}=2.571+0.08 \mathrm{Na}^{+} ; \mathrm{p}=0.01 ; \mathrm{R}^{2}=0.195\right)$. Fresh snow samples were taken up to 6 days after each fall, but samples remobilized by wind are not plotted. Several levels in each layer were sampled whenever possible.

2002). Back trajectory calculations (10 day isentropic cluster back trajectories at three different potential temperatures), using the British Atmospheric Data Center model, indicate that air masses that generated the precipitations had spent the past few days over the Antarctic continent. The back trajectory is consistent with the low $\mathrm{Na}^{+}$concentration, and explains why there is no correlation between $\left[\mathrm{Na}^{+}\right]$and $\left[\mathrm{NO}_{3}^{-}\right]$.

In summary, in fresh snows, our data suggest strongly that $\mathrm{NO}_{3}^{-}$is present as dissolved or adsorbed nitric acid taken up from the gas phase, while in aged snows $\mathrm{NO}_{3}^{-}$is present as $\mathrm{NaNO}_{3}$, presumably because of the reaction of atmospheric nitric acid with sea salt.

\subsection{Optical properties of the snow}

Since photochemistry takes place mostly in the top few $\mathrm{cm}$ or tens of $\mathrm{cm}$ in the snowpack (Simpson et al., 2002; LeeTaylor, 2002; Warren, 1982) our chemical and optical studies focused on the surface snow layers. Snowpits were dug for optical measurements under each one of the main 4 snow types discussed above and in Fig. 4. Seven snowpits were studied in detail, the objective being to obtain optical properties averaged over several snow layers found under and including each type of surface layer considered. The thin snow 
Table 3. Optical properties, for a wavelength of $400 \mathrm{~nm}$, of the snowpack at Browning Pass, studied for the 4 types of surface layers observed. The measurements are naturally averaged over several different snow layers as no one layer was thick enough to measure the optical properties in isolation. $\sigma_{\text {scatt }}$ is the scattering cross section, $\sigma_{\text {abs }}^{+}$is the absorption cross section, A is the Albedo, $\varepsilon$ is the e-folding depth, $\left[\mathrm{NO}_{3}^{-}\right]$is the mean concentration of the nitrate ion in the surface layer, and $\rho$ is the mean density of the surface layer.

\begin{tabular}{lllllll}
\hline Snow type & $\begin{array}{l}\sigma_{\text {scatt }} / \\
\mathrm{m}^{2} \mathrm{~kg}^{-1}\end{array}$ & $\begin{array}{l}\sigma_{\mathrm{abs}}^{+} / \\
\mathrm{cm}^{2} \mathrm{~kg}^{-1}\end{array}$ & $\mathrm{~A}$ & $\varepsilon / \mathrm{cm}$ & $\begin{array}{l}{\left[\mathrm{NO}_{3}^{-}\right] /} \\
\mu \mathrm{eq}\end{array}$ & $\rho / \mathrm{g} \mathrm{cm}^{-3}$ \\
\hline Hard windpack & 1.3 & 4.3 & 0.86 & 12 & 2 & 0.4 \\
Soft windpack & 6.3 & 24 & 0.85 & 3.3 & 30 & 0.4 \\
Recent windblown & 3.7 & 37 & 0.79 & 4.5 & 3 & 0.35 \\
Precipitation & 4.3 & 17 & 0.87 & 15 & 3 & 0.15 \\
\hline
\end{tabular}

layers found at Browning Pass did not allow the optical properties of just the surface layer to be obtained in isolation. In each pit, the stratigraphy had to be simplified to allow analysis of the optical data and modeling of the fluxes of nitrogen oxides leaving the snowpack. The detailed stratigraphy, calculation of $\sigma_{\text {scatt }}, \sigma_{\text {abs }}^{+}$and $\varepsilon$, and analysis of these data are described in a separate future paper, and details of the method can be found in (Fisher et al., 2005). Table 3 lists the optical and physical properties of typical snowpacks under and including each type of surface layer, together with the nitrate concentrations of these surface layers. The values of the physical parameters in Table 3 reflect in part the structure and the grain size and shape of the surface layers, and in part the effect of heterogeneities in these layers that include the presence of sub-layers and of frozen water. They also reflect the properties of the underlying layers, as no snow layer (except the fresh windblown) was thick enough to be measured in isolation (i.e. to be treated as semi-infinite). Thus values of $\sigma_{\text {scatt }}, \sigma_{\text {abs }}^{+}$and $\varepsilon$ presented in Table 3 describe the measured optical properties of the surface snow at Browning Pass, but are not to be interpreted as characteristic of the surface layer in isolation.

\subsection{Calculating molecular fluxes of $\mathrm{NO}_{2}$ and $\mathrm{HONO}$ from the Snowpack}

As shown in Fig. 4, the temporal changes in the proportion of outcropping layers and the resulting changes to the snowpack in Browning pass are complex. The total calculated flux of $\mathrm{NO}_{2}$ (or HONO) sourced from the snowpacks at Browning Pass depended on the proportions of snowpack present. The molecular flux from each surface snow layer listed in Table 3 was calculated and the weighted sum of the molecular fluxes from these snowpacks according to Fig. 4 was calculated, in order to compare with the measured molecular flux.

The snow-atmosphere radiation transfer model was run with daily measured ozone columns, each one of the 4 snow types in Table 3 and varying optical depths of cloud (asymmetry factor, $g=0.85$ and altitude $\sim 2 \mathrm{~km}$ ) to coarsely replicate the measured solar downwelling irradiance (Fig. 6).
When a coarse agreement between modeled and measured values had been achieved the values of $\mathrm{J}\left(\mathrm{NO}_{3}^{-}\right)$were calculated in a $1 \mathrm{~m}$ deep slab under each type of surface layers. Coarse agreement between the modeled and measured irradiances was refined by multiplying the calculated photolysis rates, $\mathrm{J}\left(\mathrm{NO}_{3}^{-}\right)$, by the ratio of the measured and modeled irradiance, $I$, at $350 \mathrm{~nm}, \frac{I_{\text {measured }}^{\lambda=350 \mathrm{~nm}}}{I_{\text {model }}^{\lambda=350 \mathrm{~m}}}$. While this is a crude method the adjustment is small $(\sim 20 \%)$ and allows molecular fluxes of $\mathrm{NO}_{2}$ and $\mathrm{HONO}$ to be estimated.

The depth, $\mathrm{z}$, integrated photolysis rate (transfer velocity), $v\left(\mathrm{NO}_{2}\right)$, is calculated by

$v\left(\mathrm{NO}_{2}\right)=\int J\left(\mathrm{NO}_{3}^{-} \rightarrow \mathrm{NO}_{2}\right) d z$

The molecular flux, $F$, is the product of the nitrate concentration in snow, $\left[\mathrm{NO}_{3}{ }^{-}\right]$and the transfer velocity

$F\left(\mathrm{NO}_{2}\right)=v\left(\mathrm{NO}_{2}\right) \times\left[\mathrm{NO}_{3}^{-}\right]$

The analysis assumes that (I) $\left[\mathrm{NO}_{3}^{-}\right]$is depth independent, and (II) all the photo-produced $\mathrm{NO}_{2}$ and $\mathrm{HONO}$ can exit the snowpack with $100 \%$ efficiency and do not undergo further photolysis or reaction within the snowpack. Either assumption may not always be true. Assumption (II) implies the molecular fluxes calculated in this paper are upper limits. Using Eqs. (8) and (9) the molecular flux for $\mathrm{NO}_{2}, F\left(\mathrm{NO}_{2}\right)$ was calculated and is shown in Fig. 7. The flux of HONO, $F(\mathrm{HONO})$, was estimated as an upper limit from the reaction to produce $\mathrm{NO}_{2}^{-}$(Fig. 7).

Comparing the flux estimates from the photochemical modeling with our actual measurements a significant discrepancy is obvious. While the maximum observed HONO fluxes are of the same order of magnitude as the modeled estimates, the majority ( $>90 \%$ ) of measured HONO fluxes were below $5 \mathrm{nmol} \mathrm{m}^{-2} \mathrm{~h}^{-1}$. 


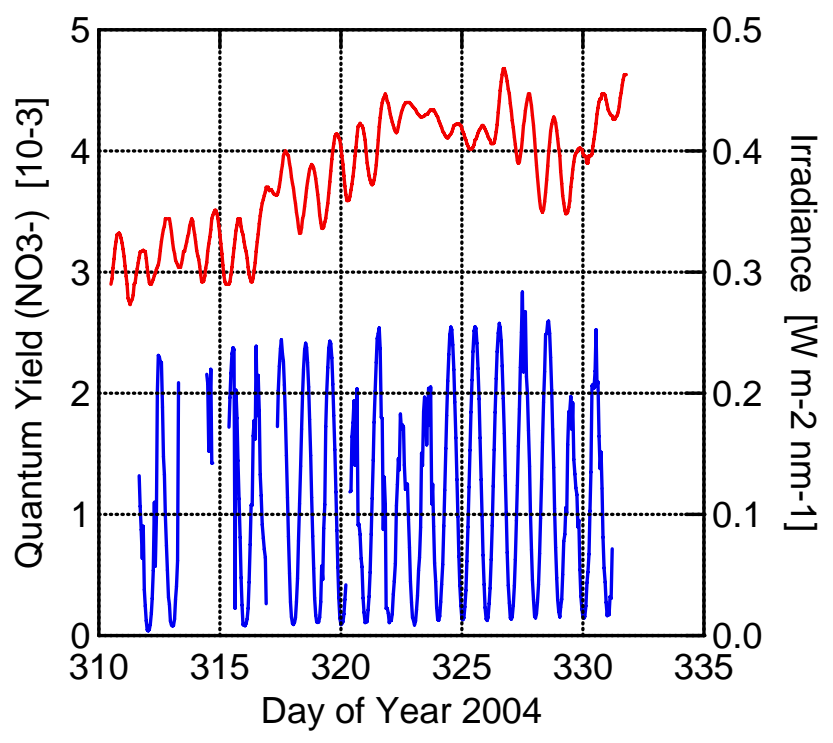

Fig. 6. The measured downwelling surface irradiance recorded throughout the campaign at $350 \mathrm{~nm}$ (blue, units of $\mathrm{W} \mathrm{m}^{-2} \mathrm{~nm}^{-1}$, right scale). Also plotted is the calculated quantum yield for nitrate photolysis to yield $\mathrm{NO}_{2}$ in ice (Reaction 1 , units of $10^{-3}$, red, left scale). The variation of the quantum yields is due to the temperature of the snowpack recorded at $12.5 \mathrm{~cm}$ depth throughout the campaign.

\section{Discussion}

\subsection{The case of aged snows}

The particularity of this study is the quasi nonexistent HONO fluxes, despite the normal to high $\mathrm{NO}_{3}^{-}$concentrations in snow. The currently hypothesized mechanism of $\mathrm{HONO}$ formation from $\mathrm{NO}_{3}^{-}$photolysis is discussed above, though the details are not well known. From this mechanism alone we would expect daily noontime maximum HONO fluxes of ca. $10 \mathrm{nmol} \mathrm{m}^{-2} \mathrm{~h}^{-1}$, which were not found. Other studies have reported or inferred HONO fluxes associated with $\mathrm{NO}_{x}$ fluxes at Alert, Summit, and South Pole (Beine et al., 2002; Honrath et al., 2002; Dibb et al., 2004). We argued that $\mathrm{NO}_{3}^{-}$is present mostly as $\mathrm{NaNO}_{3}$ in aged snows at our study site, and this seems to be peculiar. During this campaign, we also sampled snow at other nearby coastal sites such as ice tongues and inland on the plateau, all within $200 \mathrm{~km}$ from our site, and the correlation between $\mathrm{Na}^{+}$and $\mathrm{NO}_{3}^{-}$was not observed $\left(\mathrm{R}^{2}=0.02\right)$. Neither did we observe a good correlation between both ions during previous campaigns at Alert and Ny-Ålesund (Domine et al., unpublished results) and it is therefore tempting to relate both characteristics: no HONO fluxes and $\mathrm{NO}_{3}^{-}$present as a sodium salt in aged snows.

The state of salt particles in snow (i.e. solid or liquid) is not clear. From the $\mathrm{NaCl}-\mathrm{H}_{2} \mathrm{O}$ phase diagram (e.g. Hall et al., (1988)), given the ionic concentrations present and the

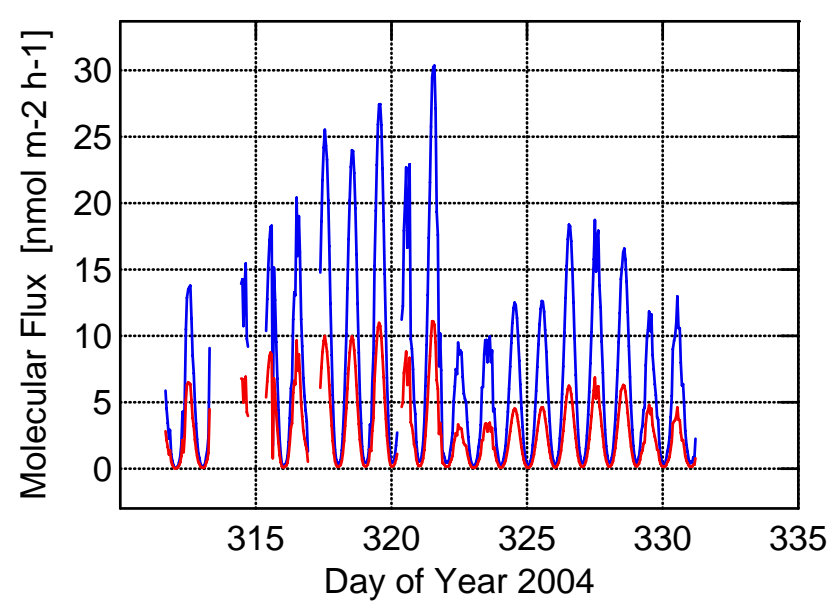

Fig. 7. Molecular fluxes of $\mathrm{NO}_{2}$ (blue line) and $\mathrm{HONO}$ (red line) estimated from photolysis of nitrate at Browning Pass during the campaign.

temperatures encountered, usually between -5 and $-15^{\circ} \mathrm{C}$, $\mathrm{NaCl}$ could not induce melting, and the concentrations of the other ions measured cannot modify this conclusion.

However, ions present in snow may favor the existence of a quasi-liquid or brine layer at the surface of snow crystals, as evidenced in laboratory experiments by Cho et al. (2002). The experiments of Cho et al. (2002) used $\mathrm{NaCl}$ concentrations much higher than those present in our snow samples, and the phase behavior for low salt concentrations still has to be established, especially since a basic extrapolation of the data of Cho et al. (2002) to the concentrations found in Browning pass suggests that it may be unimportant here. This conclusion is reached by considering bulk concentrations. Locally, a sea salt particle may induce very high ionic concentrations on a snow crystal surface, causing the formation of a quasi-liquid layer, or actual melting. To our knowledge, the impact of a salt particle on an ice surface has not been investigated and we are not able to conclude on the state of sea salt ions, and of $\mathrm{NaNO}_{3}$ on the surface of snow crystals. It is still reasonable to suggest that $\mathrm{NO}_{3}^{-}$in aged snows remains trapped in salt particles or that, even if a liquid phase is formed, $\mathrm{NO}_{3}^{-}$reactivity differs from that of $\mathrm{NO}_{3}^{-}$present as nitric acid dissolved or adsorbed in/on snow crystals (Beine et al., 2002; 2003).

Perhaps because of matrix effects in the solid state, or solvent "cage effects" in the liquid state, the products of $\mathrm{NO}_{3}^{-}$ photolysis cannot escape. Another possibility is more simply that HONO, if formed in a salt or brine medium, reacts rapidly with sea salt, presumably to form $\mathrm{NaNO}_{2}$. This reaction is plausible, although available laboratory studies are inconclusive (Vogt and Finlayson-Pitts, 1994).

\subsection{The case of fresh snows}

The case for aged snows does not explain why no fluxes were observed out of fresh snows, especially after the heavy fall of 


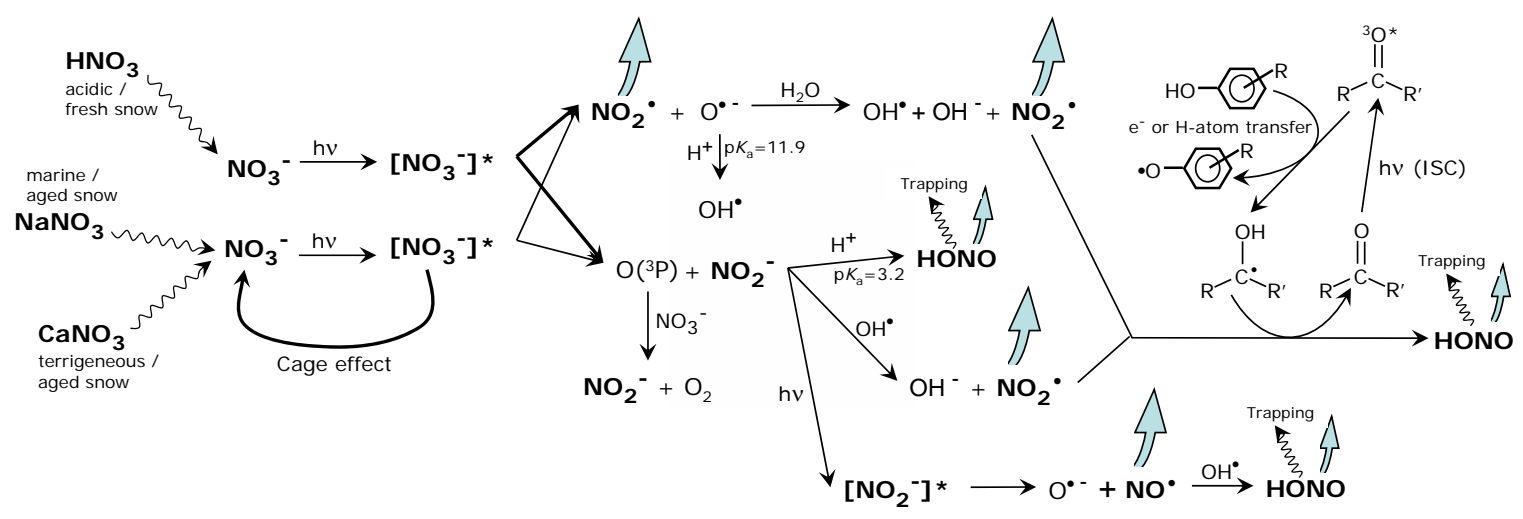

Fig. 8. Possible reaction mechanisms for the formation of $\mathrm{HONO}$ from the $\mathrm{NO}_{3}^{-}$anion. Blue arrows indicate gaseous emissions from the reaction medium, curvy arrows show transport mechanisms. Most of these chemical pathways occur in aqueous solution (Mack and Bolton, 1999), several seem to be confirmed for ice surfaces and snow (Domine and Shepson, 2002). We suggest that $\mathrm{NO}_{3}^{-}$absorbs photons regardless of its location in snow, but cage effects are predominant when $\mathrm{NO}_{3}^{-}$is present as $\mathrm{NaNO}_{3}$ or other salts. HONO, if formed, can be trapped on salt surfaces, and the efficiency of this process depends on snow composition. The reaction cycle involving photosensitized electron transfer with organics was shown in the lab (George et al., 2005; Stemmler et al., 2006).

DOY 322/323 (17-18 November), when the $\mathrm{NO}_{3}^{-}$concentration was larger than the $\mathrm{Cl}^{-}$concentration. In fact, the snowpack was particularly inactive with respect to HONO uptake/release when that snowfall covered the surface (Fig. 2), until it was partially windblown by a katabatic wind on DOY 326 (21 November). The mechanism of HONO formation from $\mathrm{NO}_{3}^{-}$photolysis is not well known. It is possible that it involves the reaction of $\mathrm{NO}_{2}$ (produced from $\mathrm{NO}_{3}^{-}$photolysis) with specific photosensitized organics (George et al., 2005; Stemmler et al., 2006). Species that are expected to efficiently transfer electrons to $\mathrm{NO}_{2}$ include electron donors such as phenols as photosensitizers in reaction cycles with aromatic ketones (George at al., 2005). The organic surface photochemistry was found in soils and other surfaces containing humic acids (Stemmler et al., 2006). If snow surfaces contain these organic chemicals, the HONO flux may depend on the concentration of photosensitizer in the snow; with low concentrations of organic photosensitizers the fluxes of HONO will be low and perhaps non-detectable.

We did not measure organic compounds in the snow or in the air, and we are therefore left to speculate on their concentrations, based on other studies. In general, Antarctic snow may be suspected of having lower concentrations of organic compounds than Arctic snow, because many of the Arctic sources such as soil dust (e.g. at Alert or Ny-Ålesund, (Domine et al., 2002) or forest fire plumes (e.g. at Summit, (Legrand and De Angelis, 1996)) are absent or reduced. Nevertheless, the sea and in particular the nearby Ross sea polynya can be a source of organic compounds, as found in snow samples near our site by Cincinelli et al. (2001). Dibb and Arsenault (2002) measured formic and acetic acids at Summit, Greenland, and at South Pole in the atmosphere and in snowpack interstitial air. Both sites are at comparable elevations and distances from the sea. They found concentra- tions about twice as high at Summit, supporting the idea that the concentrations of organic compounds in the Antarctic are lower than in the Arctic. However, Grannas et al. (2004) analyzed total organic carbon in snow and found similar values at South Pole and Summit. More importantly, the complex humic style material that Grannas et al. (2004) observed is capable of the type of photosensitization reactions that George et al. (2005) and Stemmler et al. (2006) describe. In summary, the data available on organic compounds in polar snow do not seem to support the idea that the lack of HONO fluxes could be due to a lack of organic photosensitizers. Furthermore, Dibb et al. (2004) inferred strong HONO fluxes out of the snow at South Pole, strengthening our impression that our site is peculiar.

The above considerations on the composition of Antarctic snow are general and do not allow any conclusion on the reactivity of a specific snow layer at a given site. Our monitoring of snow layers showed that fresh snow always had low ionic concentrations. Most of the mineral ion loading came from dry deposition due to wind pumping or while snow was airborne. The same mechanisms that deposit soluble mineral ions probably also deposit organic compounds. Both Arctic and Antarctic measurements cited above involved aged snows and the conclusion that they had a significant organic loading may thus not apply to our fresh snows, that may well have been depleted in organic compounds. We therefore suggest that the concentration of organic compounds was too low to support production of detectable HONO fluxes. This is consistent with our back trajectory calculations that showed that air masses generating fresh precipitation came from the continent. The highest HONO flux out of the snow was measured on DOY 327 (22 November), just after a katabatic wind partially remobilized the thick $17-18$ November snowfall that was particularly unreactive (Fig. 2). The 
katabatic wind increased the sea salt content of the snowfall snowlayer throughout, with $\mathrm{Na}^{+}$concentrations increasing from 1-5 $\mu$ eq to 10-20 $\mu$ eq. It is reasonable, although speculative at this stage, to suggest that this dry deposition of sea salt was accompanied by the deposition of organic compounds of marine origin that allowed HONO formation. The HONO flux out of the snow was short-lived, possibly because the salt subsequently trapped $\mathrm{HNO}_{3}$ as $\mathrm{NaNO}_{3}$. More field and laboratory experiments will be necessary to test these suggestions.

\section{Conclusions}

We have attempted to sum up some of the possible (photo) chemical and physical reaction pathways for HONO production suggested by this study in Fig. 8. Our somewhat speculative suggestions to explain the near-absence of detectable HONO fluxes at Browning pass is that:

(1) In aged snow samples, i.e. snows that have been remobilized by wind, $\mathrm{NO}_{3}^{-}$is present as $\mathrm{NaNO}_{3}$, and there is a significant concentration of sea salt. The absence of $\mathrm{HONO}$ emissions may be due to the fact that the $\mathrm{NO}_{3}^{-}$is present as $\mathrm{NaNO}_{3}$, which does not allow photolysis products to escape, possibly because of matrix or solvent cage effects in the phase in which $\mathrm{NaNO}_{3}$ is contained, probably $\mathrm{NaCl}$, or because HONO is taken up by sea salt.

(2) In fresh snow samples, i.e. in recent snow falls before their remobilization by wind, $\mathrm{NO}_{3}^{-}$is present as dissolved and/or adsorbed $\mathrm{HNO}_{3}$, as also suggested from studies at Alert and Ny-Ålesund (Beine et al., 2002; 2003). Products of the photolysis of $\mathrm{NO}_{3}^{-}$, including $\mathrm{HONO}$, are thus expected. A possibility is that $\mathrm{HONO}$ is produced from $\mathrm{NO}_{2}$ via electron transfer from photosensitized organic compounds, and that fresh snows had concentrations of organic photosensitizers too low for this photochemistry to be efficient. When wind deposited organic compounds to the snow, the accompanying sea salt trapped all the $\mathrm{NO}_{3}^{-}$as $\mathrm{NaNO}_{3}$, preventing HONO production as described above.

In summary; HONO production from nitrate does strongly depend on its physical (surface or volume) and chemical (ice or salt) environment. It is clear that HONO production could follow several pathways, the prevalence of one over the other depending on several aspects of snow chemistry, such as the chemical form of $\mathrm{NO}_{3}^{-}$, the concentration of organic photosensitizer, etc. Well designed laboratory experiments, with different chemistry of the (natural) ice substrate and ideally a control over the location of $\mathrm{NO}_{3}^{-}$in the substrate, seem necessary to solve the puzzle.

Acknowledgements. This work was financed by C.N.R. - IIA. The Italian Programma Nazionale di Ricerche in Antartide (PNRA; National Program for Antarctica), project 2004/6.2 "CESIP", provided access to the Italian Mario Zuchelli station. We thank the staff at the Mario Zuchelli station for their outstanding support, in particular to perform snow chemistry surveys. MDK wishes to thank NERC FSF for the loan and calibration of the GER1500 spectrometer (grant no. 447.0504), support from the Royal Society (54006.G503/24054/SM). JLF wishes to thank NERC for financial support (NER/S/A/200412177). We also acknowledge use of the British Atmospheric Data Centre (BADC) and the data supplied to it by the European Centre for Medium range Weather Forecasts (ECMWF) for back trajectory analysis. This work is part of the international multi-disciplinary Ocean-Atmosphere-Sea Ice-Snowpack (OASIS) program.

Edited by: A. Hofzumahaus

\section{References}

Allegrini, I., Ianniello, A., Montagnoli, M., Sparapani, R., and Mazzioti Gomez de Teran, C.: Carbon coated annular denuders and ion chromatography chromatographic measurements for the measurement determination of nitrogen nitrogen-containing species $\left(\mathrm{NO}_{2}\right.$ and $\left.\mathrm{NOy}\right)$ in remote atmospheres, J. Chromatogr. A., 846, 265, 1999.

Amoroso, A., Beine, H., Sparapani, J. R., and Nardino, M.: Observation of Coinciding Arctic Boundary Layer Ozone Depletion and Snow Surface Emissions of Nitrous Acid, Atmos. Environ., 40, 1949-1954, 2005.

Beine, H. J., Amoroso, A., Esposito, G., Sparapani, R., Ianniello, A., Georgiadis, T., Nardino, M., Bonasoni, P., Cristofanelli, P., and Dominé, F.: Deposition of Atmospheric Nitrous Acid on Alkaline Snow Surfaces, Geophys. Res. Lett., 32, L10808, doi:10.1029/2005GL022589, 2005.

Beine, H. J., Dominé, F., Ianniello, A., Nardino, M., Allegrini, I., Teinilä, K., and Hillamo, R.: Fluxes of Nitrates Between Snow Surfaces and the Atmosphere in the European High Arctic, http://www.copernicus.org/EGU/acp/acp/3/ 335/acp-3-335.pdf, Atmos. Chem. Phys., 3, 335-346, 2003, http://www.atmos-chem-phys.net/3/335/2003/.

Beine, H. J., Honrath, R. E., Dominé, F., Simpson, W. R., and Fuentes, J. D.: $\mathrm{NO}_{x}$ During Background and Ozone Depletion Periods at Alert: Fluxes Above the Snow Surface, J. Geophys. Res., 107(D21), 4584, doi:10.1029/2002JD002082, 2002.

Burley, J. D. and Johnson, H. S.: Ionic mechanisms for heterogeneous stratospheric reactions and ultraviolet photoabsorption cross sections for $\mathrm{NO}_{2}^{+}, \mathrm{HNO}_{3}$, and $\mathrm{NO}_{3}^{-}$in sulfuric acid, Geophys. Res. Lett., 19, 1359-1362, 1992.

Cho, H., Shepson, P. B., Barrie, L. A., Cowin, J. P., and Zaveri, R.: NMR Investigation of the Quasi-Brine Layer in Ice/Brine Mixtures, J. Phys. Chem. B, 106, 11226-11232, doi:10.1021/jp020449+, 2002.

Chu, L. and Anastasio, C.: Formation of Hydroxyl Radical from the Photolysis of Frozen Hydrogen Peroxide, J. Phys. Chem. A, 109(28), 6264-6271, 2005.

Chu, L. and Anastasio, C.: Quantum yields of hydroxyal radical and nitrogen dioxide from the photolysis of nitrate on ice, J. Phys. Chemi. A., 107, 9594-9602, 2003.

Cincinelli, A., Desideri, P. G., Lepri, L., Checchini, L., Del Bubba, M., and Udisti, R.: Marine contribution to the chemical composition of coastal and inland Antarctic snow, Int. J. Environ. Anal. Chem., 79, 283-299, 2001. 
Cotter, E. S. N., Jones, A. E., Wolff, E. W., and Bauguitte, S. J. B.: What controls photochemical $\mathrm{NO}$ and $\mathrm{NO} 2$ production from Antarctic snow? Laboratory investigation assessing the wavelength and temperature dependence, J. Geophys. Res.-Atmos., 108(D4), 4147, doi:10.1029/2002JD002602, 2003.

Couch, T. L., Sumner, A. L., Dassau, T. M., Shepson, P. B., and Honrath, R. E.: An investigation of the interaction of carbonyl compounds with the snowpack, Geophys. Res. Lett., 27(15), 2241-2244, 2000.

Davis, D., Nowack, J. B., Chen, G., Buhr, M., Arimoto, R., Hogan, A., Eisele, F., Mauldin, L., Tanner, D., Shetter, R., Lefer, B. and McMurry, P.: Unexpected high levels of NO measured at South Pole, Geophys. Res. Lett., 28, 3625-3628, 2001.

Dibb, J. E., Huey, L. G., Slusher, D. L., and Tanner, D. J.: Soluble reactive nitrogen oxides at South Pole during ISCAT 2000, Atmos. Environ., 38(32), 5399-5409, 2004.

Dibb, J. E. and Arsenault, M.: Shouldn't snowpacks be sources of monocarboxylic acids? Atmos. Environ., 36, 2513-2522, 2002.

Dominé, F., Sparapani, R., Ianniello, A., and Beine, H. J.: The origin of sea salt in snow on Arctic sea ice and in coastal regions, Atmos. Chem. Phys, 4, 2259-2271, 2004.

Dominé, F. and Shepson, P. B.: Air-Snow Interactions and Atmospheric Chemistry, Sci., 297, 1506-1510, 2002.

Dominé, F., Cabanes, A., and Legagneux, L.: Structure, microphysics, and surface area of the Arctic snowpack near Alert during ALERT 2000, Atmos. Environ., 36, 2753-2765, 2002.

Dubowski, Y., Colussi, A. J., Boxe, C., and Hoffmann, M. R.: Monotonic increase of nitrite yields in the photolysis of nitrate in ice and water between 238 and 294 K, J. Phys. Chem. A, 106(30), 6967-6971, 2002.

Dubowski, Y., Colussi, A. J., and Hoffmann, M. R.: Nitrogen dioxide release in the $302 \mathrm{~nm}$ band photolysis of spray-frozen aqueous nitrate solutions. Atmospheric implications, J. Phys. Chem. A, 105(20), 4928-4932, 2001.

Dubowski, Y. and Hoffmann, M. R.: Photochemical transformations in ice: Implications for the fate of chemical species, Geophys. Res. Lett., 27(20), 3321-3324, 2000.

Fenter, F. F., Caloz, F., and Rossi, M.: Kinetics of nitric acid uptake by salt, J. Phys. Chem., 98, 9801-9810, 1994.

Fisher, F. N., King, M. D., and Lee-Taylor, J.: Extinction of UVVisible radiation in wet mid-latitude (maritime) snow: implications for increased NOx emission, J. Geophys. Res., 110, D21301, doi:10.1029/2005JD005963, 2005.

George, C., Strekowski, R. S., Kleffmann, J., Stemmler K., and Ammann,M.: Photoenhanced uptake of gaseous $\mathrm{NO}_{2}$ on solid organic compounds: a photochemical source of HONO, Faraday Discussion, 130, 195-211, 2005.

Grannas, A. M., Shepson, P. B., and Filley, T. R.: The photochemistry and nature of organic matter in Arctic and Antarctic Snow, Global Biogeochem. Cycles, 18, GB1006, doi:10.1029/2003GB002133, 2004.

Hall, D. L., Sterner, S. M., and Bodnar, R. J.: Freezing point depression of $\mathrm{NaCl}-\mathrm{KCl}-\mathrm{H}_{2} \mathrm{O}$ solutions, Econ. Geol., 83, 197-202, 1988.

Hanisch, F. and Crowley, J. N.: The heterogeneous reactivity of gaseous nitric acid on authentic mineral dust samples, and on individual mineral and clay mineral components, Phys. Chem. Chem. Phys., 3, 2774-2482, 2001.
Honrath, R. E., Lu, Y., Peterson, M. C., Dibb, J. E., Arsenault, M. A., Cullen, N. J., and Steffen, K.: Vertical fluxes of NOx, HONO, and HNO3 above the snowpack at Summit, Greenland, Atmos. Environ., 36(15-16), 2629-2640, 2002.

Honrath, R. E., Peterson, M. C., Dziobak, M. P., Dibb, J. E., Arsenault, M. A., Green., S. A: Release of NOx from sunlightirradiated midlatitude snow, Geophys. Res. Lett., 27, 2237-2240, 2000.

King, M. D., Fisher F. N., France, J. L., and Beine H. J.: Measurement and modelling of UV radiation penetration and photolysis rates of nitrate and hydrogen peroxide in Antarctic sea ice: An estimate of the production rate of hydroxyl radicals in firstyear sea ice, J. photochemistry and photobiology A: Chemistry, Richard Wayne Honorary Special Issue, 176, 39-49, 2005.

King, M. D. and Simpson, W. R.: Extinction of UV radiation in Arctic snow at Alert, Canada (821N), J. Geophys. Res. 106(D12), 12 499-12 508, 2001.

Lee-Taylor, J. and Madronich, S.: Calculation of actinic fluxes with a coupled atmosphere-snow radiative transfer model, J. Geophys. Res.- Atmos., 107(D24), 4796, 2002.

Legrand, M. and De Angelis, M.: Light carboxylic acids in Greenland ice: a record of past forest fires and vegetation emissions from the boreal zone, J. Geophys. Res., 101, 4129-4145, 1996.

Mack, J., and Bolton, J. R.: Photochemistry of nitrite and nitrate in aqueous solution: a review, J. Photochemistry and Photobiology A: Chemistry, 128, 1-13, 1999.

Oncley, S. P., Buhr, M., Lenschow, D. H., Davis, D., and Semmer, S. R.: Observations of summertime NO fluxes and boundarylayer height at the South Pole during ISCAT 2000 using scalar similarity, Atmos. Environ., 38(32), 5389-5398, 2004.

Phillips, G. R. and Simpson, W. R.: Verification of snowpack radiation transfer models using actinometry, J. Geophys. Res., 110, D08306, doi:10.1029/2004JD005552, 2005.

Simpson, W. R., King, M. D., Beine, H., Honrath, R. E., and X. Zhou: Radiation-transfer modeling of snow-pack photochemical processes during ALERT 2000, Atmos. Environ., 36, 2663 2670, 2002.

Sokolov, O. and Abbatt, J. P. D.: Competitive adsorption of atmospheric trace gases onto ice at $228 \mathrm{~K}: \mathrm{HNO}_{3} / \mathrm{HCl}, 1-$ butanol/acetic acid and 1-butanol/HCl, Geophys. Res. Lett., 29, 1851, 2002.

Stemmler, K., Ammann, M., Donders, C., Kleffmann, J., and George, C.: Photosensitized reduction of nitrogen dioxide on humic acid as source of nitrous acid, Nature, 440, 195-198, doi:10.1038/nature04603, 2006.

Thibert, E. and Dominé, F.: Thermodynamics and kinetics of the solid solution of $\mathrm{HNO}_{3}$ in ice, J. Phys. Chem. B., 102, 44324439, 1998.

Vogt, R. and Finlayson-Pitts, B. J.: Tropospheric HONO and reactions of oxides of nitrogen with $\mathrm{NaCl}$, Geophys. Res. Lett., 21, 2291-2294, 1994.

Warren, S.: Optical properties of snow, Rev. Geophys. Space Phys., 20, 67-89, 1982.

Zhou, X., Beine, H. J., Honrath, R. E., Fuentes, J. D., Simpson, W., Shepson, P. B., and Bottenheim, J.: Snowpack Photochemical Production as a Source for HONO in the Arctic Boundary Layer in Spring Time, Geophys. Res. Lett., 28(21), 4087-4090, 2001. 